\title{
Preliminary Study in Finding Alternative Materials: A Study on Traditional Malay Stage-House Typology and Construction in Bangka Island
}

\author{
Elita Nuraeny ${ }^{1, *}$, Dalhar Susanto ${ }^{2}$, and Kemas Ridwan Kurniawan ${ }^{1}$ \\ ${ }^{123}$ Department of Architecture, Universitas Indonesia, Indonesia
}

\begin{abstract}
Woods is the most favoured material for traditional and vernacular housing construction in Indonesia because it is cheap, versatile, and easily accessible. However, the practice of wood constructions has become a laborious task nowadays, with woods availability dwindles and becomes highly unaffordable. Advanced technology in our everyday routines and habits is also indicated as one of many aspects, influencing shifts in today's vernacular and traditional architecture in Indonesia. Therefore, finding an affordable alternative is crucial to maintain and develop vernacular typologies of traditional houses in Indonesia. This paper focuses on Malay stage-house, a traditional housing typology in Bangka Island, which is in dilemma of being left by the local people. The scarcity of wood makes the material unaffordable for locals, forcing them to adopt a more modern housing typology instead of traditional ones. This paper uses methodologies of literature research, interviews, and field study on Malay stage-house in Muntok City, Bangka. Result and conclusion in this paper, therefore, becomes a preliminary study to propose an alternative and sustainable materials that is available and financially affordable for locals in Muntok without overlooking the authenticity of Malay's traditional typology and ideology in Bangka Island.
\end{abstract}

\section{Introduction}

Bangka is known to be a diverse and multi-cultural region, due to its strategic geographical location. Other than the native residence, people of Bangka came from around the world such as Chinese, Arabs, and - during the Dutch colonial government-Europeans. These cultural groups lived side by side in Bangka [1][2], generating countless of possibilities in cultural hybridity [1]. This hybridity, moreover, can be observed through the locals' housing typologies across Bangka.

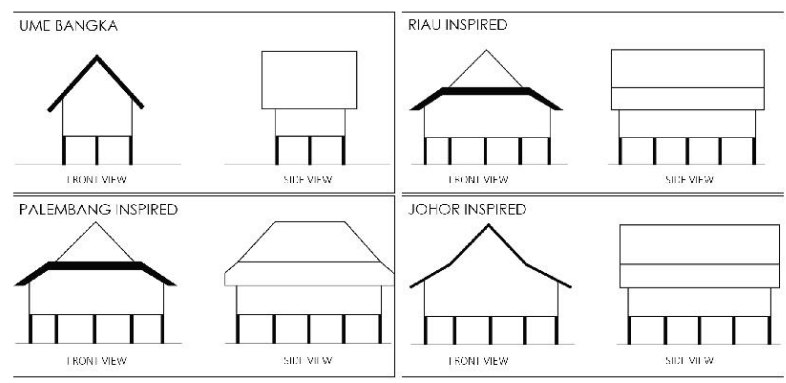

Fig. 1. Various traditional housing typologies found in Bangka Island (source: Nuraeny, 2018).
The earliest vernacular house is Ume Bangka which was built by native people who had lived in Bangka since $1500 \mathrm{BC}$ as the second wave of Austronesiansalso known as the Deutro Melayu people [1]. They lived as nomadic tribe who collected food from around the area. This activity - collecting food and migrating from one place to another-is called berume, hence the name of Ume Bangka which came from their close proximity between their natural environment and houses [1]. As indigenous people were exposed to modernisation, Ume Bangka as the vernacular dwelling typology of Bangka Island adapts to other typologies; Malay housing typology is one of them. The difference between these typologies can be seen from their roof: traditional house that was inspired by Palembang's traditional house has a limasan roof (a prism with extended roof). Another typology is inspired by Riau with folded roof, and lastly - a bit different from Riau's roof-is inspired from Johor. The last two typologies (Riau and Johor) might look similar due to their folded roof.

The diversity in traditional housing typology came as the result of tin mining practice in Bangka Island. Chinese, Arabs, and Malays who came in $19^{\text {th }}$ Century to work in tin mining industry or to sell their goods later decided to stay in Bangka Island. They adapted Bangka's traditional housing typology and climate condition, then assimilated their own traditional houses

Corresponding author: elitanuraeni@gmail.com 
to create a new stage-house typology which had characteristic from both their country of origin and Bangka Island itself.

However, the tin mining industry influences "the development of the social, cultural, economic, and political structure" [3], and thus becomes a doubleedged sword to the future of traditional stage-house in Bangka. When the Dutch came, they monopolised the tin mining industry and also changed people's dwelling habit through their earlier regional planning. From living berume in small dusun (hamlet), natives were forced to move alongside the new roads built by the Dutch [1][3][4]. It all started after Perang Bangka (Bangka War) in 1812-1851, led by Depati Amir [1]. To prevent another rebellion, the Dutch government forced locals to "settle in the kampung on the outskirt of the city" [2], removing them from the forest as well as their tradition of berume [1]. After this regulation, natives were introduced to diverse communities which then inspired hybridity of housing typologies in Bangka Island.

When Indonesia declared their independency and tin mining as primary source of economy in Bangka, natives - particularly those who lived in Muntok Citywere "increasingly dependent on PT. Tambang Timah" [3]. However, the company and Indonesian government saw that traditional stage-houses representing backwardness and under-developed society when compared to the 'modern' and 'civilised' European settlements in Bangka [3]. The government instead built new houses, because 'new' means 'developed' and modern [3]. Traditional stage-house was neglected by the government and received minimum concern as well as financial support to maintain its survival.

Embracing local identity through traditional housing is essential for the people in Bangka Island. With tin mining industry no longer being their main source of economy, tourism can be an alternative income for people in Bangka Island today. Emphasising on the local wisdom and traditional aspect will differentiate Bangka from other regions in Indonesia that will attract tourists. Preserving traditional stage-houses, therefore, is beneficial to promote Bangka's local identity, both nationally and internationally. Finding an alternative material that resonate with local cultural heritage and local wisdom in craftsmanship of wood construction to maintain traditional stage-houses will be the main focus in this paper.

\section{Methods}

This paper aims to propose alternative materials or regulation to construct traditional Malay stage-houses while staying true to the ideology and cultural heritage in Bangka. As a preliminary study, literature research becomes the primary method in investigating various traditional stage-house typologies in Bangka Island, especially the Malay stage-houses which were influenced by traditional houses in Palembang, Riau, and Johor. Conducted in Muntok City, West Bangka, interviewing locals - especially those who lived in stagehouses in Bangka - around the topic of renovating and repairing their houses is another method used in this paper to answer the question on craftsmanship and material knowledge of local's builders. Further discussion in this paper will be separated into three topics, focusing on (1) materials availability and geographical condition in Bangka Island; (3) craftmanship and local knowledge in building construction; and (4) local identity and culture.

Important readings to analyse the connection between site, material, and local culture are Amos Rapoport's book, House Form and Culture and Kemas Kurniawan's final report on his research in Tipologi Arsitektur Rumah Panggung Kayu Melayu dan Tradisi Membangun sebagai Acuan bagi Kegiatan Revitalisasi Kota Pusaka di Kota Muntok (Architectural Typologies of Malay Stage-Houses and the Built Tradition to Revitalised the Heritage City in Muntok). Gaudenz Domenig's book, Timber Orientation in the Traditional Architecture of Indonesia, will be a secondary resource to discuss the craftmanship and knowledge in building construction. Although Domenig's book talked about traditional technique in Indonesian vernacular architecture in general, his writings on eastern Indonesia - where Bangka Island is included-will set some basic thoughts on traditional building method in this region. Furthermore, Domenig's book focuses on timber as material and cultural identity in traditional houses; similar to Malay stage-houses constructed in Bangka Island that use wood as its main material.

\section{Result and Discussion}

Built by carpenters, the overall shape of traditional Malay stage-house is rectangular with its floor raised from 50-150 centimetre off the ground [1]. The idea on rising the base floor was to protect the house from flooding which occurs almost every year. The overall look of these traditional stage-houses can be divided into three levels: kolong, induk ibu, and loteng [4]: kolong is the lowest level and used as storage or to keep their animals. Induk is the central living area, where social interaction between family and their neighbours took place. Lastly, is loteng or attic to store valuable belongings [1][4].

For the interior, the main living space is separated into three main areas: front, middle, and rear areas. There are lots of seating areas in the central living space especially at the entrance where the resident welcomes their guests. The middle area is used as sleeping quarters and another area to socialise with close friend and family, while the rear area is used as washing, cooking, and dining area. There is no indoor bathroom or toilet, but an outdoor well is provided in the traditional stagehouse to bath and wash [4]. Figure 2 shows us typical stage-house plan in Bangka Island that is inspired by Palembang's limasan roof. 


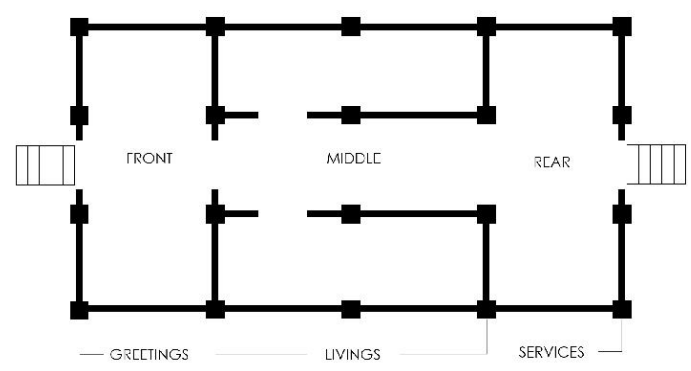

Fig. 2. The interior of typical stage-houses in Bangka (a plan view of other stage-houses in Bangka, inspired by Palembang's slanted roof, source: Nuraeny, 2018).

Wood is the primary material to construct traditional stage-house in Bangka Island; it is used to construct the structure, partitions and walls, even for flooring. Kelekak - a traditional plantation in Bangka Island - is a tradition representing the intimacy between nature and people in Bangka Island. A Tradition that in the late $19^{\text {th }}$ Century strictly controlled by the Dutch government to encourage forest preservation [4], but most importantly to ensure power over the natives. With kelekak being taken from the local tradition, local's access to timbers was also gone.

Today, the practice of kelekak may not be suitable especially around the issue of global warming. Clearing out some area in the forest to create new plantation might be a harmful activity to the earth's future. Considering the life cycle to evaluate the environmental impacts of the material extraction, production, and transportation phases [5], therefore, it is essential if these traditional Malay stage-houses can be made out of sustainable material.

\subsection{Geographical and Climate Condition, and Available Material in Bangka Island}

To find the right material to construct stage-house that is suitable for the $21^{\text {st }}$ Century, understanding the geographical and climate in Bangka Island is essential. "The physical environment of man, especially the built environment, has not been and still is not, controlled by the designer" [6], means that the condition of the environment has a role in the creation of these stagehouses: its typology and its source of materials. Reading back to the origin of Ume Bangka where it was located in the forest, therefore, timber becomes a standard material for most of these traditional houses. Wood, also, can be easily acquired.

However, collecting timber after the resettlement in the 1851 when people were forced to live far away from the forest-becomes a complicated and expensive task. Moreover, in the same timeline, the Dutch government also released a regulation on forest felling to preserve water reservoir [4]; a regulation that further restricted locals to cut down trees as building material. Without access to woods, people are forced to use other materials which available around them. The traditional stage- houses then replaced by smaller blockhouses built on the ground [4], while the remaining stage-houses are in poor condition due to the owners' financial incapability. This situation raised some question: is wood still the best option to construct Malay stage-house? If so, is it possible to acquire the material? To answer this question, we need to view the current location of where people live: in the urban kampung.

The remaining traditional wooden stage-houses are passed down from generation to generation. $\mathrm{Bu}$ Yana, an owner of a Palembang-inspired stage-house, inherited the stage-house from his ancestor who built the house around 1800s. However, costly maintenance and difficulty to acquire woods are two of common problem faced by current generation in these stage-houses. Based on an interview with Ansori, a craftsman in Muntok City, to construct these stage-houses, certain types of woods are used, such as ulin wood (ironwood) for structure; meranti wood and nyatoh wood to construct walls and roof battens; and medang batu wood is cut into planks for the floor. However, ironwood, nyatoh, and meranti are no longer available in Bangka Island. To acquire these woods, people order it from another island. People who could not afford to export the raw material are made some adjustments to their stage-houses.

Unfortunately, the way people use alternative materials to construct stage-house was often done recklessly. For example, locals replace the nipa leaves roof with asbestos - a dangerous material with toxic fallout that is harmful to human's respiratory system. Using asbestos is not sustainable because it will not decompose, unlike nipa palm leaves which are biodegradable. This adjustment shall be conducted in precautious on the ecological footprint and shall discharge no more waste than can be absorbed by their environment [8]. Reducing the carbon footprint is essential, therefore finding the right material that is available and sustainable will reflect traditional Malay stage-houses' relationship with its surrounding environment.

As mentioned by Kurniawan, "many of the new indigenous wooden houses were constructed using recycled materials" to save money [4]. The contractor also keens on using other materials than wood such as bricks, stones, and terracotta from the local factories [3]. Other than availability factor, these alternative materials are fireproof compared to traditional wooden houses which almost every ten years caught in catastrophical fire incident [4]. However, completely replacing woods with concrete will eliminate the traditional stage-houses because concrete is heavier than woods. The idea of having a stage-house no longer possible with such heavy material. To maintain stage-house typology, concrete and stone might be useful to reinforce the lower part of the structure (the kolong). Wood, however, can be used in other part of the stage-house which will reduce the wood quantity needed to construct a house, and with that, people can save money. 


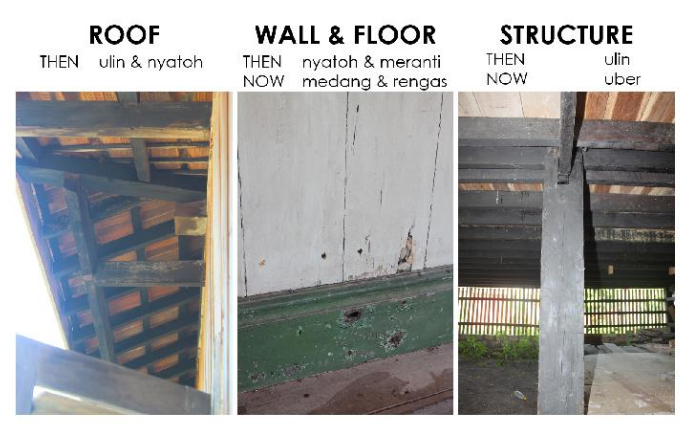

Fig. 3. Various types of woods in constructing traditional stage-houses in Bangka, which influenced by Palembang's pyramid roof (source: Findanavy and Syahid, 2018).

The main problem in using woods for stage-houses nowadays lays in the difficulty to acquire it, and thus doubled the cost than using other materials such as concrete, bricks, and steels. Based on an interview with Fakhrizal Abubakar, an owner of traditional Malay stage-house in Kampung Tanjung, Muntok, acquiring ulin wood and mendaru wood is not possible because these types of woods are no longer available in Bangka. Medang batu wood - another favourable material used in traditional wood constructions for flooring and wood panelling - is available, however, does not possess the same quality as in the past. People are forced to use another type of woods to replace ulin wood and mendaru wood which is not strong and durable enough to withstand heavy loads and extreme climate in Bangka.

Wood, as mentioned by Andrea Deplazes (2005), is a good insulating material with thermal conductivity around $0.13 \mathrm{~W} / \mathrm{mK}$ for softwood-pines, agathis, and jumuju - and $0.20 \mathrm{~W} / \mathrm{mK}$ for hardwood - such as teak, camphour, meranti, and ironwood-making wood an ideal material for construction in tropical climate [13][14]. In Bangka, especially in Muntok City area, hardwood is no longer available. Moreover, using solid wood to construct stage-house might not a best option in sustainability perspective, because almost $25 \%$ in material consumption will lead to tropical forest destruction. All forests in Indonesia will be extinct in 2022 if people continue to exploit the forest [13]. Therefore, finding alternative materials and adapting to available material around us are needed.

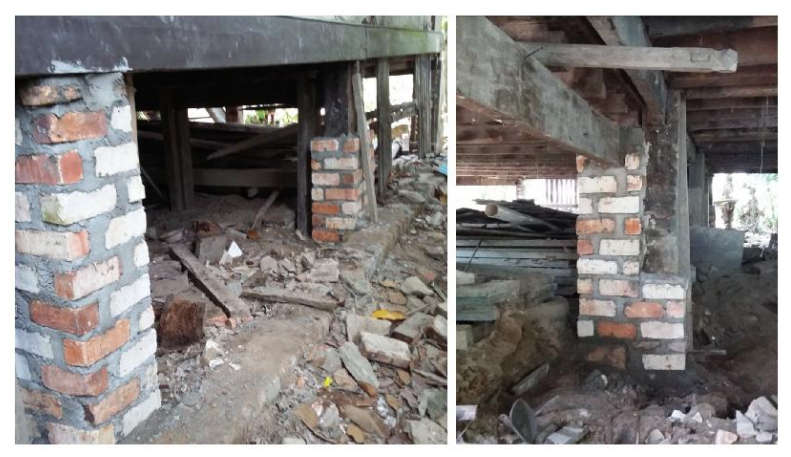

Fig. 4. Reinforcing the structure of a traditional stage-house by replacing or integrating the decayed wood with concrete and bricks (source: Yana, unknown year).
Material adaptation had been done by the locals, especially in Muntok City, West Bangka. A traditional stage-house built by $\mathrm{Bu}$ Yana and her family, an old house from $1800 \mathrm{~s}$, was renovated. As the owner, Bu Yana wanted to raise the floor of her house and reinforced the rotted wood supporting her house. To minimise cost and time, $\mathrm{Bu}$ Yana decided to use concrete and bricks to strengthen the old structure. The decaying ironwood was cut down and a hydraulic jack was inserted to support the house until the new kolong structure is completed.

\subsection{Craftsmanship and Knowledge to Build Traditional Malay Stage-House}

Rapoport says that investigating any traditional and vernacular architecture should not be viewed from the intellectual development of its designer because both traditional and vernacular architecture is nonchronological [6]. Rapoport, in continuation to his previous statement, offers a different perspective into traditional and vernacular architecture by "analysing the buildings themselves rather than trying to trace their development" [6]. Rapoport then argues that "materials, construction, and technology are best treated as modifying factors, rather than form determinants, because they decide neither what is to be built not its form" [6], resulting in his conclusion that changing the material will not necessarily changing the form of the house. Another argument said that traditional dwellings adapt to current demands and continue to change following the societal actions, internal and externally [15]. Therefore, understanding the culture behind specific skills and craftsmanship is important; an approach this paper tries to gain.

As mentioned by Gaudenz Domenig (2008), uncoverted timber or natural woods was commonly used in the eastern part of Indonesia [12]. Bangka, as part of the eastern sphere of Indonesia, is included in this category. All parts in Bangka's stage-house-kolong, induk, and loteng-utilise woods as their structure, partition, roof, and even flooring [4]. Ironwood, mendaru wood, and medang wood are commonly used to build most of traditional stage-houses in Bangka. To create a strong structure, people use ironwood and mendaru wood to construct the main structure while lighter wood such as medang wood is used for flooring and wall-panelling. Traditional wooden houses in Indonesia are commonly thicker around the root or lowest structure than the roof, following the natural position - root to the top - to balance and strengthen the house [4]. In traditional stage-houses in Bangka, people implemented similar idea of following tree's position by aligning their wall panels vertically.

Traditional houses in Bangka were mostly built by carpenters instead of architects. They learned construction by copying the Malay-Chinese migrants from Johor. The technique of Johor's experienced carpenter then followed by the local craftsmen in Bangka [4]. Although there is no clear record on who build the remaining stage-houses in Bangka, the knowledge of 
constructing houses with timber is apparent from time to time. For example, positioning the edge beams of a rectangular structure in either clockwise or counterclockwise intends to optimise the distribution of weight towards each pillar. Domenig continues, "if all elements were oriented in the same direction, the tichker and heavier ends would be on one side and the structure would not be well balanced" [12]. The same notion has been done in most Malay stage-house typologies found in Muntok City where the rooftop structure is built parallel to the street for aesthetic and convenience purposes [7]. Ansori, a builder in Muntok City, admits that he learned wood constructions by examining the current stage-house and tries to imitate it. Other construction knowledge he cannot acquire from the physical house, he learnt it from a senior builder who came from Jepara - a well-known region for their woodwork in Central Java--1,268 kilometres from Muntok, West Bangka.

Finding carpenters in Bangka today is difficult. No longer people are interested to study wood construction. Instead, people prefer to study bricks and stones construction because it is more profitable. From interviewing locals, construction workers who worked with steels and stones, are hired to fix stage-houses. Ansori, for example, is not a carpenter but a welder. It is important for the future generation of builders to understand the characteristic of the material they are using as well as the characteristic of their traditional Malay housing typology. It is also crucial to train or pass down knowledge in the craftsmanship of traditional Bangka's stage-house to the younger generation. Recreating or rebuilding a traditional Malay stage-house might be a great option to understand knowledge in wood joineries and constructions.

\subsection{As Local Identity and Cultural Heritage-In the Making!}

From the general view across the world, traditional wooden houses are often portrayed as cheap and inferior to its stone-built counterparts [9][10], because it looks less modern and challenging than concrete, steels, and glass. On the contrary, wood presents challenges to local craftsmen in a form of wood joineries and how to choose the right type of wood to create a strong house.

The negative perception around traditional wooden houses in Bangka, however, does not stop on the material; it continues to the typology, resulting on locals to completely change their traditional housing typology to a more modern one. This attitude is moulded since 1851 where the Dutch viewed locals as their inferior workers. This inferiority and sentiment towards traditional housing typology in Bangka Island continued to the early $20^{\text {th }}$ Century after independency of Indonesia. In Muntok City, instead of conserving or preserving the damage houses, Indonesian government decided to demolish the traditional Malay houses and construct a new building because it is more expensive to preserve the traditional building. Also, the government thought that traditional wooden houses as under developed, bad, and represent backwardness [4]. Vernacular architecture, therefore, is often regarded as an outdated or dysfunctional alien in the modern world; it stands in the way of modernity, progress, and development [11]. This phenomenon reflects what Rapoport mentions in his book, that "building a house is a cultural phenomenon, its form and organisation are greatly influenced by the cultural milieu to which it belongs" [6]. This phenomenon, however, is not ideal for the people of Bangka for they will lose their cultural identity and heritage if they continued to perceive traditional stage-house as a negative aspect of their everyday lives.

Unaccepting the traditional stage-houses typology has a consequence in balancing the relationship between locals and their environment. Without acknowledging the importance of traditional housing typology, people in Bangka are susceptible to losing their values and heritage. The disappearance of traditional stage-house from the locals' daily lives had caused some significant loss regarding originality in housing construction around Bangka [6]. Moreover, based on a field research in July 2018 at Muntok City, Ume Bangka typology was no longer discovered, while the rest of traditional stagehouses_-influenced by Palembang, Riau, Johor, and Malacca - are left in poor condition.

The importance of promoting stage-house back in the society contains in its value as a mediator to enhance the relationship between the native and their environment. Therefore, promoting the greatness of traditional stage-house to modern lives stands as a significant factor to find alternative materials. As Catherine O'Brien mentions: "our natural desire for our well-being is inextricably associated with the well-being of others and the natural environment" [9]. O'Brien calls this balance as 'sustainable happiness', and it can be used to foster sustainable behaviour; one of them is selecting the right alternative material that held the characteristic of the original material [9]. "Sustainable happiness invites opportunities to enhance our quality of life and contribute to individual, community, and global well-being" [9] has spoken true to find the right material to preserve Malay stage-house in Bangka Island for the next hundreds of years. Vernacular architecture should not be perceived as a historical remain from the past [11], but to have meaning and usefulness in daily lives as identity and cultural heritage of Bangka. Residents of Malay stage-houses we interviewed in Muntok agreed to preserve and conserve their traditional stage-houses. However, once again, financial and material difficulties become the main problem to maintain stage-houses in Bangka.

\section{Conclusion}

It is important to preserve traditional housing typology in Bangka Island as cultural identity and heritage. These Malay-inspired traditional stage-house has potential to represent the indigenous people, their tradition as well as their historical narrative. Also, traditional stage-house 
becomes a silent witness of Bangka's historic role in national aspects. However, before proposing for alternative materials, preserving and conserving the remaining Malay stage-houses become crucial, to raise awareness on Bangka's traditional building technique amongst locals. Conservation and preservation are also crucial for future generation on their local craftsmanship and material knowledge. Then, finding alternative materials to build traditional Malay stage-houses shall be the implementation to preserve wooden stage-houses across Bangka Island with sustainable material. With basic knowledge on their traditional building technique, it is easier for locals to solve their material problem by utilising other available materials such as bricks and concrete, while some other preserving the authenticity of wood construction. Discussions in this subject is not yet finished; further research to map the available materials as well as design a preservation programme are needed.

Thanks to the Sustainable, Housing, and Technology research cluster and Architectural Theory and History research cluster in the Department of Architecture Universitas Indonesia for their support in writing this paper. To Fakhrizal Abubakar, the Head of Tin Mining Museum in Muntok, and Ansori for sharing his thoughts on traditional stage-houses in Bangka and how to preserve it. $\mathrm{Bu}$ Yana, Pak Lung, and Pak Farhan who welcomed us to their houses and spared time to talk with us. We appreciate his contribution to this research and to the sustainability of stage-houses in Bangka. Also, many thanks to the Ministry of Research, Technology, and Higher Education in Indonesia for their financial support.

\section{References}

1. A. Elvian, Perang Bangka Tahun 1812-1815 Masehi (Dinas Kebudayaan Pariwisata Pemuda dan Olahraga, Pangkalinang, 2016).

2. K.R. Kurniawan, et. al., Makara Seri Sos. Hum. 17, 2 (2013).

3. K.R. Kurniawan, Postcolonial History of Architecture and Urbanism: Power and Space of Indonesian Tin Mining in Bangka Islands (VDM VA. Verlag Dr. Müller GmbH \& Co., Saarbrücken, 2005).

4. K.R. Kurniawan, The Hybrid Architecture of Colonial Tin Mining Town of Muntok (UI-Press, Depok, 2013).

5. S. Bhochhibhoya, et.al., Mountain R\&D 37, 1 (2017).

6. A. Rapoport, House Form and Culture (PrenticeHall Inc., New Jersey, 1969).

7. K.R. Kurniawan, et. al., "Tipologi Arsitektur Rumah Panggung Kayu Melayu dan Tradisi Membangun sebagai Acuan bagi Kegiatan Revitalisasi Kota Pusaka di Kota Muntok", final report for Penelitian Unggulan Perguruan Tinggi (PUPT) research grant, 2017 (unpublished).

8. G. Klunder, J. Housing \& the Built Env. 19, 1 (2004).

9. C. O’Brien, Can. J. of Edu. 36, 4 (2013).
10. L. Välja, Place \& Location: Stud. In Env. Aest. \& Semiotics 6 (2008).

11. M. Vellinga, Persp. In Vernacular Arch. 13, 2 (2006/2007).

12. G. Domenig, Bijdragen tot de Taal-, Land- en Volkenkunde 164, 4, (2008).

13. D. Susanto, Widyarko, INSIST 2, 1 (2017).

14. A. Deplazes (ed.), Constructing Architecture: Material Processes Structures (Birkenhäuser, Basel, 2005).

15. T.H. Panjaitan, Int. J. of Tech. 5 (2017). 